\title{
'Living God, renew and transform us' - 26th General Council of the World Communion of Reformed Churches, in Leipzig, Germany, 29 June to 07 July 2017

\begin{tabular}{|c|c|}
\hline $\begin{array}{l}\text { Author: } \\
\text { Jürgen Moltm }\end{array}$ & $a n n^{1,2}$ \\
\hline $\begin{array}{l}\text { Affiliations: } \\
{ }^{1} \text { University of } \\
\text { Germany }\end{array}$ & Tübingen, \\
\hline $\begin{array}{l}{ }^{2} \text { Department } \\
\text { and Christian } \\
\text { of Theology, } \\
\text { Pretoria, Sout }\end{array}$ & $\begin{array}{l}\text { Dogmatics } \\
\text { Ethics, Faculty } \\
\text { niversity of } \\
\text { h Africa }\end{array}$ \\
\hline $\begin{array}{l}\text { Research Proj } \\
\text { Project Leade } \\
\text { Project Numb }\end{array}$ & $\begin{array}{l}\text { ect Registration: } \\
\text { : J. Buitendag (D) } \\
\text { er: } 02402343\end{array}$ \\
\hline $\begin{array}{l}\text { Description } \\
\text { Prof. Dr J. Mol } \\
\text { contributes to } \\
\text { project, 'Unive } \\
\text { and Theology' } \\
\text { Prof. Dr Johan } \\
\text { Department o } \\
\text { and Christian } \\
\text { Dean, Faculty } \\
\text { University of }\end{array}$ & $\begin{array}{l}\text { tmann } \\
\text { the research } \\
\text { ersity, Education } \\
\text { directed by } \\
\text { Buitendag, } \\
\text { f Dogmatics } \\
\text { Ethics, and } \\
\text { of Theology, } \\
\text { retoria. }\end{array}$ \\
\hline $\begin{array}{l}\text { Correspondin } \\
\text { Andries van A } \\
\text { andries.vanaa }\end{array}$ & $\begin{array}{l}\text { g author: } \\
\text { arde, } \\
\text { de@aosis.co.za }\end{array}$ \\
\hline $\begin{array}{l}\text { Dates: } \\
\text { Received: } 09 \\
\text { Accepted: } 09 \\
\text { Published: } 04\end{array}$ & $\begin{array}{l}\text { ct. } 2017 \\
\text { Oct. } 2017 \\
\text { Dec. } 2017\end{array}$ \\
\hline $\begin{array}{l}\text { How to cite th } \\
\text { Moltmann, J., } \\
\text { God, renew ar } \\
\text { us" - 26th Ge } \\
\text { the World Cor } \\
\text { Reformed Chu } \\
\text { Leipzig, Germ } \\
07 \text { July } 2017 \text { ', } \\
\text { Studies/Theol } \\
73(1), \text { a4836. } \\
\text { org/10.4102/ }\end{array}$ & $\begin{array}{l}\text { is article: } \\
\text { 2017, '"Living } \\
\text { hd transform } \\
\text { heral Council of } \\
\text { nmunion of } \\
\text { Irches, in } \\
\text { any, } 29 \text { June to } \\
\text { HTS Teologiese } \\
\text { ggical Studies } \\
\text { https://doi. } \\
\text { ts.v73i1.4836 }\end{array}$ \\
\hline $\begin{array}{l}\text { Copyright: } \\
\text { (C) 2017. The } \\
\text { Licensee: AOS } \\
\text { is licensed unc } \\
\text { Creative Comr } \\
\text { Attribution Lic }\end{array}$ & $\begin{array}{l}\text { uthors. } \\
\text { IS. This work } \\
\text { der the } \\
\text { nons } \\
\text { ense. }\end{array}$ \\
\hline Read online: & \\
\hline 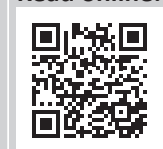 & $\begin{array}{l}\text { Scan this } Q R \\
\text { code with your } \\
\text { smart phone or } \\
\text { mobile device } \\
\text { to read online. }\end{array}$ \\
\hline
\end{tabular}

This article aims at exploring the theme 'Living God, renew and transform us' under the following headings: the living God and the gods of death, the desolation of atheism and the sun of righteousness, just law and the fullness of life. The author relates the 'God of Life' to a 'theology embracing life'. He links the 'gods of death' to racism, capitalism and terrorism in which we 'encounter a new religion of death'. He points out that Christianity is a religion of joy in God and sets out to illustrate this with selected biblical texts. In the section 'The desolation of atheism', the author argues that modern atheism offers a 'reduced life'. To make his point, he refers to his own personal experience and the theological 'protest atheism' which arose in the 19th century. The author concludes by stating that atheism offers nothing positive. In the final section, 'The sun of righteousness, just law and the fullness of life', the author addresses issues of justice. In referring to the Reformation doctrine on justification, the author states that the justification of victims requires confessio oris, rising up from humiliation and forgiveness.

\section{Introduction}

This theme of the World Communion of Reformed Churches is a prayer that sounds like a hoarse cry from the depths:

We have grown old, tired and cold - renew us, give us a new heart!

We have become confused and uncertain - transform us. Awaken a new spirit within us!

Hear the answer of the living God from my favourite verse in Psalms 103:

Who satisfies you with good as long as you live so that your youth is renewed like the eagle's. (Ps 103:5)

I first spoke at a General Council of the World Alliance of Reformed Churches (WARC) (Presbyterian and Congregational) in Nairobi in 1970, 47 years ago. I followed the World Council of Churches' Programme to Combat Racism and in 1976 I contributed to WARC's human rights programme 'The theological basis of human rights'. I was present at the tragic act in Ottawa in 1982 when black South Africans refused to take Holy Communion with white South Africans and the latter went away during the night. That same year, 1982, the Belhar Confession appeared in South Africa and paved the way for the disappearance of apartheid ideology from South African churches. I welcomed the covenanting of the Reformed Churches in Accra in 2004.

The World Communion of Reformed Churches has only spoken up loudly every 7 years, but then it has always been close to the 'living God' and close to human need.

What is on the agenda for the Christian life in a world that has grown old, tired and cold, and for confused, uncertain human beings?

I have three points:

- the living God and the gods of death

- the joy of the living God and the desolation of atheism

- the sun of righteousness, just law and the fullness of life.

Note: The former president of the World Communion of Reformed Churches (WCRC), Prof. Jerry Pillay, invited Prof Jürgen Moltmann to speak at the General Council of the WCRC in Leipzig, Germany, from 29th June to 9th July 2017. In a special session on Theology, he was requested to focus on the future of Reformed Theology from the perspective of the theme of the General Council, Living God, renew and transform us. 


\section{The living God and the gods of death}

To what extent is the true God a 'living God'?

The living God is also the eternal God. Eternal life is God's substance. Eternal life is not only unending life but also life of such intensity that it flows over and calls forth other life. All finite life stems from the infinite life of the living God. Hence, all finite life longs for the eternal source of life:

My soul thirsts for God,

for the living God. (Ps 42:2)

My heart and my flesh sing for joy to the living God. (Ps 84:2)

Spiritual longing is not enough, so the soul 'thirsts' for the source of life 'as a deer longs for flowing streams'. Body and soul are not divided: the body cries for life as well. Life always hungers for life. Life is brought to life through other life. The 'living God' makes us thirsty and hungry for life and causes us to want more divine life in our human life: 'We need more life in life' as Wolf Biermann (see Shreve 1980) once sang.

The 'living God' seems attractive through God's own liveliness. God's living power goes forth from itself and seeks the thirsty souls and bodies of people hungry for life. There is movement in God's eternal life. The living God goes forth in Christ and brings life. He looks for the lost. He lights a lamp in the 'dark night' of the soul. The living God is not 'unmoving' like the god of Aristotle. God can move the divine self and be moved by the cries of suffering creatures (Ex 3:7).

Where the living God creates or bears life, there arises fullness of life and fulfilment of life. 'My heart and my flesh sing for joy to the living God'. There our lives are eternally affirmed, there arise lost for life and joy in life with all our bodily senses. There arises a fervent love of this life. When our 'heart and flesh sing for joy', spirituality and vitality are one. There arises a new spirituality of the senses and the earth. The spirit (of life) is poured out on all flesh (Ac 2:17). The joy of body and soul in the living God is at the same time the joy of the living God in the body and soul of God's beloved creatures.

I see how a theology embracing life is arising everywhere in world Christianity: Pope Francis showed the way to Catholic theology with the encyclicals Gaudium Evangelii (24 November 2013) and Laudato si (24 May 2015). In Reformed theology, an Ohn theology has emerged in Korea (see e.g. Dommen \& Bratt 2007; The world of Ohn theology 2016) and an 'oopmaak' (gateway) theology is coming up in South Africa, which is a theology of opening (Faculty of Theology, University of Pretoria 2017).

\section{The dead gods - Gods of death}

The German racial ideology began with Nazi terror on our streets and ended in Auschwitz with 6 million murdered
Jews. For the Nordic race that was destined to take world supremacy, the eastern Europe peoples were considered Untermenschen. With the attack on the Soviet Union in 1941, the 'Plan for the East' was that 30 million people should starve in order to provide Lebensraum, space to live, for the German race. The German Army (Wehrmacht) let over 2 million Russian prisoners of war die of hunger and thirst in camps. The German race-godhead not only brought appalling suffering upon the peoples but also burdened the German people with intolerable guilt.

For a long time, the racial boundary ran between white people and black people: white people were good and black people were bad. In the United States and Africa, white racism has not disappeared. It is deeply ingrained in our souls. Angels are all white and devils are always black. My daughter discovered a black angel in Venice that now hangs on our Christmas tree.

The gods of the fatherlands have the First World War on their consciences: the 'European Ur-disaster'. 'Holy fatherland', we boys sang with our fathers: 'a man must defend his fatherland', and dying for the fatherland was considered a sacrifice. The European great powers annihilated each other with all their power from 1914 to 1918 and sacrificed their youth, although there would have been ways of making peace. In France and Belgium the crosses stand in serried ranks in soldiers' cemeteries just as their owners stood to attention in the barracks yard.

What a tragedy! When my generation was expected to die for the Führer of the German fatherland, we ran blindly into death. Only afterwards did it become clear that there is no fatherland in a dictatorship. Our patriotism no longer applies to our own people but to the democratic constitution, with human rights as the fundamental rights of all people. The fatherland-god is a dead god and a god who was sacrificed in vain on the battlefields of the First World War and the Second World War. May God preserve us from 'America first! The first will be last, Jesus said' (Mt 19:30).

The god of capitalism is a god who promises wealth and produces poverty. The god of capitalism divides our societies and consumes what we have in common. There is enough for all, but 60 million people are threatened by starvation. The freedom of the 'free market economy' does not serve the life of all people. Freedom in a society of privileged and unprivileged is good for the former but not for the latter. The only thing that benefits disadvantaged groups is just laws, with international organisations to enforce them. Long before Marx, Mammon termed it the most common idol on the earth. Let us resist this idolatry.

The 21st century has invented suicide bombers: or more accurately, suicidal mass murderers. In terrorists, we encounter a new 'religion of death'. 'Your young people love 
life', Mullah Omar from the Taliban told western journalists, ${ }^{1}$ 'Our young people love death'. After the mass murder in Madrid on 11 March 2004, ${ }^{2}$ a letter claiming responsibility was found with the same content: 'You love life, we love death'. A German who joined the Taliban in Afghanistan declared: 'We don't want to win, we want to kill and be killed'. Why? I think that killing bestows power, the absolute, divine power over life and death. That is why terrorists seek maximum publicity. Spreading terror brings huge pleasure. We saw this love of death in European Fascism: 'Viva la muerte', cried an old Fascist general in the Spanish Civil War (see Moltmann 2007:347; 2013:33).

Terrorism arises in people's hearts and minds and must be overcome in people's hearts and minds. It is the language of peace, not of violence, that creates life. Terrorists 'only understand the language of force' (see Croty 2005:69; Fishman 2002), we are told from all sides. But this 'language of force' has caused the number of terrorists to soar from a few hundred at the time of bin Laden to tens of thousands in Islamic State of Iraq and Syria (ISIS) and Boko Haram today.

It is good when joint Christian-and-Muslim peace initiatives deter young people from volunteering to kill and being killed in Syria, winning them back for life and love. It is good when Muslims and Christians care for abused child soldiers and heal them from the trauma of death. The living God does not demand sacrifices, but instead sacrifices for love. Faith creates life, idolatry is lethal.

\section{The joy of the living God and the desolation of atheism}

Christianity is a religion of joy in God. At any rate, the Christian faith in the resurrection makes life into a festival, 'a festival without end', as church father Athanasius said one Easter Day in Alexandria (Egypt) (see Brother Roger of Taizé 2007:33). Let us measure the positive dimensions of 'great joy' in the broad spaces of God, who is closer to us than we think, and widens our lives more than we suspect. Joy is the strength to live, momentum to love and pleasure in the creative beginning. We are made for enjoyment.

Let us look first into the Psalms in the Old Testament: God's love and presence call forth joy, not fear:

You show me the path of life.

In your presence there is fullness of joy;

In your right hand are pleasures forevermore. (Ps 16:11)

This enlivening presence of God is often described as the 'shining face' of God (Num 6:24; cf. Pattison 2016:86). When

1.Editor: for example, Bette Dam, a Dutch journalist who reported for CNN, the Global Post and the Guardian, Spiegel Online 30 July 2015, 'Mullah Omar biographer, "The world's most mysterious political leader"', viewed 08 October 2017, from www. spiegel.de > English Site > World > Afghanistan.

2.Editor: the Spanish prime minister, José María Aznar, used the expression 'mass murder', when ' $[\mathrm{m}$ ] ore than 190 people were killed today [11 March 2004] and many more injured in a series of rush-hour explosions at Madrid train stations' (Jeffery 2004). does a face shine? When someone wants to make a gift - or when a mother looks at her newborn child, her face shines. God's shining face radiates the blessing that brings fulfilment to human life and heightens its festive side.

Joy is amazingly also linked with God's judgement: when God comes, it is to judge the earth and joy will bring nature to bloom:

(...) let the sea roar, and all that fills it; let the field exult, and everything in it.

Then shall all the trees of the forest sing for joy before the Lord;

for he comes, he comes to judge the earth. He will judge the world in righteousness. (Ps 96:11-13)

When God comes to judge the earth, it is like the sun rising. God will straighten up the bent and make the withered green again, heal the sick, revive those who are flagging and give the weary back their youth.

When God comes to humans, there is a double change of direction - in God and in people. God turns from the 'hidden face' (hester panim) to the 'shining face'. This change in God - away from aversion to human wrongdoing to the kindness of God's grace - calls forth a corresponding change in the person concerned:

You have turned my mourning - into dancing;

You have taken off my sackcloth and clothed me with joy. (Ps 30:12)

And when the ransomed of the Lord return, everlasting joy shall be upon their heads, they shall obtain joy and gladness, and sorrow and sighing shall flee away (Is 35:10). God will rejoice with those who have been saved:

$$
\begin{aligned}
& \text { He will rejoice over you with gladness, } \\
& \text { he will renew you in his love, } \\
& \text { he will exult over you with loud singing. (Zph 3:17) }
\end{aligned}
$$

Is not that a wonderful picture? The exultant God, rejoicing with his ransomed creatures?

From this compilation from the Psalms and the Old Testament Prophets, we see a great, wonderful harmony of joy - God's joy - the joy of the earth, the joy of the ransomed. Back in 1940, Helmut Gollwitzer (1965:168-177; cf. Moltmann 2007:246-249) called his exposition of Luke 15 'God's joy'.

Joy is more original than faith. After all, what does the gifting God expect other than that the gifted human rejoices? In Greek, charis [grace] and chara [joy] are linguistically very close. Paul can use faith and joy interchangeably when he writes:

We are workers with you for your joy, because you stand firm in the faith. (2 Cor 1:24)

The Pharisees publicly reprimanded Jesus' amazing behaviour towards 'tax collectors and sinners' ('This fellow welcomes sinners and eats with them', Lk 15:2). Luke 
interprets it by recounting three parables: of the lost-andfound sheep, of the lost-and-found coin and of the lost-andfound son (Lk 15:1-32).

There will be more joy in heaven over one sinner who repents than over 99 righteous persons who need no repentance. (Lk 15:7)

This theology is not exactly correct: the 'joy in heaven' is quite right, but Jesus did not only accept repentant sinners and eat with them. In addition, the lost sheep could not contribute much to being found, let alone the lost coin. The 'joy in heaven' lies first with the seeking-and-finding God:

When he has found it, he lays it on his shoulders and rejoices. (Lk 15:5)

The prodigal son (German: 'lost son') is the only one who repents. He turns away from his misery in a foreign land and goes back towards his father's house, wanting to tell him: 'Father I have sinned against heaven and before you' (Lk 15:21). Yet before he can make this special confession, his father gets in first: 'But while he was still far off, his father saw him and was filled with compassion; he ran and put his arms around him and kissed him' (Lk 15:20). Only then does the found son confess that he was lost, yet his father is not bothered; he rejoices:

This son of mine was dead and is alive again; he was lost and is found. And they began to celebrate. (Lk 15:24)

The God who seeks and finds the lost rejoices, and those who are found rejoice with God. Finding a lost person is like awakening someone who has died. Rejoicing in that means tuning in to God's joy. It is about welcoming life, where there was death.

The living God is a God who brings life. The dead gods are the gods of death.

\section{The desolation of atheism}

Compared with the fullness of life in the living God, modern atheism offers a reduced life. Philosopher Jürgen Habermas ([2005] 2008:309) ${ }^{3}$ famously echoed Max Weber ([1926] 1988:324) in saying he was 'religiously unmusical' ${ }^{4}$ We can live without music, but it is a poorer life. We can live without religion, but is a reduced life. The modern world directs its residents towards humanist ideals, but mostly towards naturalist or capitalist approaches to life. A life that has abandoned the living God is, so to speak, a life without an overhead light, without transcendence. A life that has lost transcendence becomes a life without selftranscendence. Your relationship to yourself dries up and your conscience may be twisted. Yet rationales for atheism may differ greatly.

\footnotetext{
3.Editor inserts reference to Habermas.

4.Editor: in her biography of her husband Max Weber, Marianne Weber-Schnitter ([1926] 1988:324) refers to his letter to Ferdinand Toennies, dated 09 February 1909: It is true that I am absolutely unmusical religiously and I have no need or 1909: It is true that I am absolutely unmusical religiously and Thave no need or ability to erect any psychic edifices of a religious character within me. But a thorough
self-examination has told me that I am neither antireligious nor irreligious (p. 324).
}

I experienced humanist atheism in my own family. My grandfather Johannes Moltmann was Grand Master of the Hamburg Masonic lodge, but had to leave it because of his criticism of religion. He agreed with the humanist ideals of Gottfried Ephraim Lessing and the religious critique of Ludwig Feuerbach. He wanted to make the human being great and yet yearned for a 'future God', the title of his last essay. I experienced the atheism of the Nazi dictatorship in my personal life. That was racism and idolatry: Give an order, Führer, and we will follow you. This was political. It was idolatry, and the idol was called Hitler. In the German Democratic Republic ('East Germany') I also got to know Stalinist atheism, with its motto: 'Without God and sunny weather, we will reap our crops together'.

In the 19th century, there was theological 'protest atheism'. People protested against God because of the suffering of the innocent of the earth. They protested against God and the state, because throne and altar had allied themselves against the people. 'Neither God nor state', proclaimed anarchist Michael Bakunin (1814-1876) in Tsarist Russia (see Bakunin [1871] [1970] 2017:17; Moltmann 2015:3-22). In the 20th century, Catholic novelist Heinrich Bohl (in Moltmann 2007:64) said: 'I don't like these atheists. They are always talking about God'. Today protest atheism is rare in Europe. Banality atheism is widespread. People have lost their faith in God and hardly feel the loss. Human beings have become 'economic animals' and allowed life to be commodified. The 'post-secular' generation has moved beyond theism and atheism, faith and idolatry.

When atheism wins and theism disappears, what will become of atheism? It will disappear too, because, along with theism, atheism will also destroy itself. It offers nothing positive!

\section{The sun of righteousness and the justification of the victims}

The World Communion of Reformed Churches has now approved the Joint Declaration on the Doctrine of Justification agreed by the Lutheran World Federation and the Roman Catholic Church. Yet there is something missing at the heart of Reformation theology. The Truth and Reconciliation Commission in South Africa brought it to light: the justification of the victims of the sins committed.

The Reformation doctrine on justification arose from the medieval sacrament of penitence. The power of evil is called sin - godlessness. We talk of 'the forgiveness of sins by God's grace alone, by faith'. That is also true and important but it is only half the truth. The sinner who committed the wrongdoing is forgiven, but where do the victims of this sin stand? We pray 'forgive us or sins', but where are the victims of our sinful action? The sacrament of penitence is one-sided, focusing on the perpetrator. The doctrine of justification forgets the victims. There is a gap here in the Christian doctrine of grace. That is already recognisable in the teaching on sin of the apostle Paul. In Romans 7, he writes, honestly and self-critically: 
For I do not do the good I want, but the evil I do not want is what I do. Now if I do what I do not want, it is no longer I that do it, but sin that dwells within me. (Rm 7:19-20)

Why does Paul not direct our attention to those to whom he has done evil and not done good? Why is he only concerned about himself?

In the Old Testament Psalms, we find God's righteousness in the forgiveness of sins: 'In your righteousness deliver me and rescue $\mathrm{me}^{\prime}$ Ps 71 , recalling Luther's discovery of the righteousness that justifies. However, God's righteousness is on the side of the victims of sin: 'The Lord works vindication and justice for all who are oppressed' (Ps 103:6). 'He works justice for the poor, the widows and orphans'.

God's righteousness is not a justice that only determines good and evil. It is a creative righteousness that works justice. For the victims, it is a righteousness that brings them justice. For the evil-doers it is a righteousness that reinstates justice and puts things to rights. The first issue is not the penitence of the perpetrators but the pain of the victims. What can the justification of victims look like? Here is a suggestion.

The first step is like the sacrament of penitence: confessio oris. It is a step into the light of truth. The victims of injustice and violence must .emerge not only from their suffering but, even more, from their spiritual humiliation. This closes their mouth. In the case of sexual violence, there is the additional shame at the violation they have suffered. They need a free space recognising their suffering, so that they can cry out their pain. They need a listening ear, someone to whom they can tell their story, so that they can regain self-respect. The victimiser's confession of guilt can help them here. But they should not wait for it because they also have to be liberated from fixation on the victimiser - they must not remain 'victims' forever. In the God 'who works justice for those who suffer violence', they rediscover their human dignity. They also need a protective space of a community in which they can feel recognised.

The second step is raising up the victims from humiliation, and their raising their heads to God. The victims too need repentance. It is a turning away from self-pity and self-hate into the wideness of a loving self-affirmation. That is the precondition for the third step.

Not reprisals but forgiveness makes us free. Everyone who suffers a wrongdoing or some offence will dream of revenge. That is quite natural. But if we return evil for evil, we do not gain justice, but only a doubling of evil. 'Do not be overcome by evil', Paul rightly says (Rm 12:21). Nor by the evil by which evil is repaid. Whoever murders a murderer is also a murderer. 'Overcome evil with good', Paul continues. If we forgive those who sin against us, we not only do them good, but also ourselves: we overcome the evil that has entered our lives.

\section{Just law}

It is well known that Reformed Christianity has a passion for 'law and justice'. After all, Calvin was a lawyer and our fathers regarded the tertius usus as the goal of the law and the actual use of the law: 'Actions speak louder than words'. Freed for just life! All peoples suffer today from social impoverishment and are crying for social justice. For over 40 years, we have heard the lament of governments that, despite all efforts, the divide between rich and poor is widening. You just need to read the Poverty and Wealth Reports in Germany. Not only in less developed countries does a small, rich upper class dominate a mass of poor people, but also in the industrialised democracies the gap between astronomic manager salaries and the income of unemployed people is grotesque.

Democracy is founded not only on the freedom of its citizens, but also on their equality. The democratic idea of equality is incompatible with an economic system that produces ever greater inequality among people. Without equality in life opportunities and without equality of life conditions there is a loss of common good and social cohesion. With 'economic deregulation' (Ronald Reagan, now Donald Trump, the current president of the United States), politics does not control the economy, the economy controls politics.

In a society of very high and very low earners, freedom for the most vulnerable can be fatal. Only just laws protect life. The alternative to poverty is not wealth. The alternative to poverty is community. You can live in poverty if it is something everyone puts up with together. It is only injustice that makes poverty hard to bear. The contempt for solidarity shown by rich tax-evaders enrages people. When everyone is in the same situation, they help each other mutual. If, however, equality ceases because some are winners and the others losers, that is the end of mutual assistance.

By community, I mean manageable social security systems based on solidarity and also the welfare state. The internal cohesion of a society is social balance and social peace. Social peace calls for just social legislation. The state must reclaim the right to regulate the economy and the finance because it is the only one able to enforce social legislation. With the present economic and financial globalisation, international organisations from the European Union to the United Nations must adopt and enforce rules for just economic dealings and for fair trade. Rather than a 'free' market economy, I am for a just market economy because it is the only one able to enforce social legislation.

'Competition' and 'competitiveness' are strong driving forces, certainly, but only in the framework of a common life, that is only within the boundaries of social justice. There are areas of life that must not be subjected to the expansive logic of the market because they follow other laws. Patients are not 'customers' of our hospitals and students are not 'consumers' of our disciplines at the universities.

'Security' must not become a 'commodity' that only the rich can afford with their private security firms. The state and the police are responsible for the security of citizens; otherwise, societies will be divided into gated communities and slums. 
In gated communities, the police are unnecessary, and slums are places where they do not enter at night. When that happens, the state is turning into a 'failed state'. Security is not a commodity; it is a fundamental right of citizens. It must not be privatised. The modern state has a monopoly on the use of force and must not delegate this to others.

\section{Human rights and the rights of nature}

For the last 40 years, I have followed and participated in the discussion about the ecological turn taken by theology. I recently reread WARC's statement of 1976 'The Theological Basis of Human Rights' and its 1989 paper called 'Rights of Future Generations - Rights of Nature - Proposal for enlarging the Universal Declaration of Human Rights'. I was surprised to see how up-to-date they are today. They are also unique in that they develop the legal side of human rights and also the rights of future generations.

The rights of nature are seen as the basis for solving the environmental crisis. That is something I have not found in any of the theological books on the ecological crisis. It bears the signature of Reformed theology:

Community with all creation on this earth nonetheless remains a pipe-dream unless it is realized within the community of law for all life. Such an earthly legal community must open the human legal community to rights of other forms of life and to rights of nature. We must open human laws within universal laws of the life of the earth, if we want to survive. (Studies of the WARC 19, 1990:24 - see Van der Bent 1990:254-266)

We explained human rights from God's law, as suggested by the biblical account of God-likeness (imago Dei). Human beings are created in the image of God and become God's covenant partners and, in the community of Christ, sons and daughters of God and heirs to God's kingdom. That applies to individuals and to the human community.

In these studies, we therefore took up the United Nations' Universal Declaration of Human Rights (UDHR) of 1948 and its International Covenant on Civil and Political Rights of $1966,{ }^{5}$ in order to balance individual rights (civil and political) with collective (social, economic and cultural) rights. At the time we attached particular importance to a Reformed right of resistance (Studies of the WARC 19, 1990:66) As assignments for further work, we named 'the rights of future generations', because people live in generations, and 'the rights of nature', as people live in a life community with the earth.

A small working group of lawyers and theologians led by Lukas Vischer met regularly in Geneva and presented its

5.Editor: The International Covenant on Civil and Political Rights (ICCPR) is a multilateral treaty adopted by the United Nations General Assembly with resolution 2200A (XXI) on 16 December 1966, and in force from 23 March 1976 in accordance with Article 49 of the covenant. Article 49 allowed that the covenant will enter into force three months after the date of the deposit of the thirty-fifth instrument of force three months after the date of the deposit of the thirty-fifth instrument of
ratification or accession. The covenant commits its parties to respect the civil and ratification or accession. The covenant commits its parties to respect the civil and
political rights of individuals, including the right to life, freedom of religion, freedom of speech, freedom of assembly, electoral rights and rights to due process and a fair of speech, freedom of assembly, electoral rights and rights to due process and a fair
trial. (viewed 07 October 2017, from see https://en.wikipedia.org/wiki/ International_Covenant_on_Civil_and_Political_Rights). findings at the WARC General Council in 1989 in Seoul, Korea (Studies from the WARC, No 19). The 'rights of nature', the earth, of plants and trees, of animals and the ecosystems were developed theologically from the covenant with Noah in Genesis 9. The resolutions (12-13) were sent to the United Nations organisation and also to the individual nations. Because of these resolutions, Dr Lukas Vischer ${ }^{6}$ and Prof. Peter Saladin, ${ }^{7}$ Geneva, were able to influence legislation in Switzerland.

The World Communion of Reformed Churches should take up these resolutions from Seoul again and keep working on them. They can then complement the well-known Earth Charter (2000) which evolved following the UN's Earth Summit of 1992 in Rio de Janeiro. ${ }^{8}$

The Accra Confession of 2004 cannot be praised highly enough (World Communion of Reformed Churches 2004). Finally, we have a document in clear language with a series of affirmations ('We believe in ...') and statements of rejection, saying 'no' ('We reject ...'/ 'Wir sagen "Nein"') $)^{9}$ instead of the many pointless 'dialogues'. The 'God of capitalism' is met with the confession of the living God. And the call for justice for the poor and the Earth is raised globally in addressing economic and financial 'globalisation'. The work on just laws conducted in WARC from 1976 to 1989 must be combined with the Accra Confession. Accra 2004 must be supplemented by Seoul 1989: the 'rights of future generations' and the 'rights of nature' must be refined and enhanced. And there is something else: every Reformed confession mentions the right of popular resistance It is found in the Confessio Scotica of 1560 (Art. 14) (see Plasger \& Freudenberg 2005:124-150) and in the 1572 Vindiciae contra Tyrannos by Philippe Duplessis Mornay (see McGrath 2012:262). It is found in the Belhar Confession of 1982 (see Nimmo \& Fergusson 2016:291) and in the Accra Confession (see World Communion of Reformed Churches 2004]. This right of resistance presupposes a quite specific understanding of the state: covenant theology instead of sovereignty doctrine and democracy instead of authoritarian rule. Who should implement human rights and the rights of nature better than a just state? We have neglected constitutional theory for too long.

6.Editor: Rev. Dr Lukas Vischer (1926-1928): was a Swiss Reformed theologian author, and advocate of ecumenical dialogue among the world's Christian churches. Vischer studied theology in Basel, Göttingen, and Strasbourg and spent one semester at Oxford University ... Vischer's tenure with the World Council of Churches began in 1961 with his appointment as research secretary on the council's Commission on Faith and Order. From 1962 to 1965, he was a WCC observer at the Second Vatican Council. He was director of the Faith and Order Commission from 1966 to 1979, then director of the Protestant Office for Ecumenicism in Bern. He was moderator of the theological department of the World Alliance of Reformed Churches from 1982 to 1989 (Wikipedia 2017).

7.Prof Peter Saladin (1935-1997) was: '[f]rom 1972 to 1975 ... Professor of Public Law at the University of Basel. From 1976 to 1997 he was a Professor of Public Issues and Administrative Law at the University of Bern. His work focused on ecological, ethical and public law of churches, besides he was interested in the rights of future generations and of nature' (Drolshammer \& Cottier 2015).

8.The Earth Charter initiative was signed by the Earth Charter Commission on 29 June 2000 at the Peace Palace in The Hague, viewed 07 October 2017, from www.unesco. org/education/tlsf/mods/theme_a/img/02_earthcharter.pdf

9.Author: The phrases in brackets are added for clarity. Originally, the German version of the Confession was 'wir verwerfen' and 'wir sagen "Nein"'. 'We reject' does not quite convey the clear language. 


\section{Fullness of life}

When the 'sun of righteousness' (Ml 4) rises, the sun of life rises at the same time. It is the same in spring: the sun awakens everything to life, the flowers spring out of the ground, the trees turn green and the animals are aroused from sleep. It is like that when the 'spirit of life' is 'poured out' on all living things: humanity begins to blossom, strength grows, there is hope for the future, the diversity of life unfolds and a wealth of talents comes to fruition. 'Let a hundred flowers bloom', Mao once said. We need a vision for the future for the new scientific and technological possibilities we have today; otherwise, they will be used for the death and destruction of humanity. 'Fullness of life' is that kind of vision of the future, reaching far beyond what is possible here - into eternal life.

The cry for justice always comes too late, when violence and wrongdoing make the life of vulnerable people difficult. But it has to come, if we take the future vision seriously. Yet negating the negative does not lead to anything positive. Overcoming wrongdoing does not of itself produce what is right and nonviolence does not lead to service for peace. That is why we should not only talk to the poor about their poverty, and the victims of violent systems must not always remain victims.

The poor are only 'poor' by comparison with the rich. In my experience, they do not want only to be approached about what they do not have and are not, but rather about what they are and what they can do. The victims of violent acts and systems must not always remain fixated on the perpetrators and violent systems - they must free themselves from a fixation on the perpetrators and find their way to themselves again.

Who defines them actually as 'poor' or 'victims' or 'oppressed' or 'losers'? It is the wealthy or those who have 'made it', or the violent systems. When we stand up for the poor and the victims of oppression, who are we? The poor or the non-poor, the victims or the non-victims? The message of Accra was a necessary message to the industrialised world to the nonpoor and the non-oppressed. It was still not a message from the 'poor' or the 'victims'. If in future, we await not only the 'sun of righteousness' but also, first and foremost, the sun of life we will be seized by a passion for the life of the 'poor' and the 'victims', for life together.

Anyone who trusts the living God does not just see the world in terms of its reality. Realists do that and they always arrive too late. Anyone who trusts the future sees the world according to its potential. 'All things are possible for one who believes, because all things are possible to God'. All reality is surrounded by a sea of possibilities. All realities are realised possibilities or non-realised alternatives. For a long time, historians told history as though it was a fatal necessity: it had to happen! Today we recognise that the First World War did not have to happen; there were options for peace but no one seized them.
We will, therefore, become seekers of possibilities of life and justice, and will avoid the recognisable options of death and annihilation. In the cockpit of a plane, I found the motto: 'Think ahead of the airplane'. In order to recognise the objective chances for life, we need to be especially attentive: Watch and pray, says the New Testament, and the new emphasis is on watching. In order to discern favourable opportunities for life, we must stretch our imagination, our creative fantasy. For our daily lives, we need our imagination in order to look after our interests. Why do we not use it for the Kingdom of God and its righteousness, and for life and its beauty? You do not need to be a prophet to do that. You just need to wake up and, with Christ, hope and love.

All great organisations of church life, mission and diaconal ministry were founded by Christian 'inventors'. They had an idea, were alert and seized their chances. We think of the Reformers Luther and Calvin, 500 years ago, or of John Wesley and Count Zinzendorf 300 years ago, or of the founding fathers of the huge churches in Korea, or of the women and men of new South Africa. They all were seized by God's creative spirit and created something new.

\section{'Living God, renew and transform us'}

That happens when the 'sun of righteousness' lights our path. Since the coming of Christ into this world, it has shone over the earth. The sun has already risen. The future of life has already begun.

\section{Acknowledgements Competing interests}

The author declares that he has no financial or personal relationships which may have inappropriately influenced him in writing this article.

\section{References}

Bakunin, M., [1871] [1970] 2017, God and the state, transl. B.R Tucker, Dover Publications, New York.

Crotty, W.J., 2005, Democratic development \& political terrorism: The global perspective, Northeastern University Press, Boston, MA

Dam, B., 2015, 'Mullah Omar biographer, "The world's most mysterious political leader"', Spiegel Online 30 July, viewed 08 October 2017, from www.spiegel.de English Site , World , Afghanistan

Dommen, E. \& Bratt, J.D., 2007, John Calvin rediscovered: The impact of his social and economic thought, Westminster John Knox Press, Louisville, KY, (Princeton Theology Seminary Studies in Reformed Theology and History).

Drolshammer, J. \& Cottier, T. (eds.), 2015, The anthology of Swiss legal culture, viewed 08 October 2017, from www.legalanthology.ch/americanization/5...of.../petersaladin/

Faculty of Theology, University of Pretoria, 2017, Gateway to ... Oopmaak van die hekke ..., Published by the Faculty of Theology, University of Pretoria, in commemoration of 100 years of academic excellence, Crysalis Printing \& Publishing Solutions, SENTIK, Pretoria.

Fishman, A., 2002, 'Iraq and Jordan will become one Hashemite state', Yediot Ahronot, 6 September, Article 144930, viewed 16 November 2017, from Yediot Organization: http://groups.google.com/

Francis, Holy Father, 24 November 2013, 'Apostolic exhortation Evangelii Gaudium of the Holy Father Francis to the bishops, clergy, consecrated persons and the lay faithful on the proclamation of the gospel in today's world', viewed 09 Octobe 2017, from http://w2.vatican.va/.../papa-francesco_esortazione-ap_20131124_ evangelii-gaudium.html

Francis, Holy Father, 24 May 2015, 'Encyclical Letter Laudato Si of the Holy Father Francis on care for our common hope', viewed 09 October 2017, from http://w2.vatican. va/.../en/encyclicals/.../papa-francesco_20150524_enciclica-laudato-si.htm 
Gollwitzer, H., 1965, Die Freude Gottes: Einführung in das Lukasevangeliums, Burkhardthaus-Verlag, Berlin.

Habermas, J., [2005] 2008, Between naturalism and religion: Philosophical essays, transl. C. Cronin, Polity Press, Cambridge, MA.

International Covenant on Civil and Political Rights (ICCPR), 1966, United Nations, viewed 07 October 2017, from https://en.wikipedia.org/wiki/International_ Covenant_on_Civil_and_Political_Rights

Jeffery, S., 2004, 'Bombers wreak havoc in Madrid', The Guardian, 11 March, viewed 08 October 2017, from https://www.theguardian.com > World > Spain

McGrath, A.E., 2012, Reformation thought: An introduction, Wiley, Chichester.

Moltmann, J., 2007, A broad place: An autobiography, transl. M. Kohl, SCM Press, London.

Moltmann, J., 2013, Just peace: Ecumenical, intercultural, and interdisciplinary perspectives, F. Enns \& A. Mosher (eds.), with foreword by O. Fykse Tveit, Wipf \& Stock, Eugene, OR, (Pickwick Publications).

Moltmann, J., 2015, 'European political theology', in G. Hovey \& E. Phillips (eds.), The Cambridge companion to political theology, pp. 3-22, Cambridge University Press, Cambridge.

Nimmo, P.T. \& Fergusson, D.A.S., 2016, The Cambridge companion to reformed theology, Cambridge University Press, Cambridge.

Pattison, S., 2016, Saving face: Enfacement, shame, theology, Routledge, London.
Plasger, G. \& Freudenberg, M., 2005, Reformierte Bekenntnisschriften: Eine Auswahl von den Anfängen bis zur Gegenwart, Vandenhoeck \& Ruprecht, Göttingen.

Roger, B., 2007, Glimmers of happiness, GIA Publications, Chicago, IL.

Shreve, J., 1980, 'There is a life before death: The Wolf Biermann story', Graduate Student Theses, Dissertations, \& Professional Papers, University of Montana, viewed 05 October 2017, from http://scholarworks.umt.edu/cgi/viewcontent. cgi?article $=6297 \&$ context $=$ etd

The world of Ohn theology, 2016, transl. M. Yong Kim, Presbyterian and Theological Seminary Press, Seoul.

Universal Declaration of Human Rights (UDHR), 1948, United Nations Regional information Centre (UNRIC), and the Office of the United Nations High Commissioner for Human Rights - Regional Office for Europe (OHCHR), New York, viewed 07 October 2017, from www.ohchr.org/EN/UDHR/Documents/UDHR Translations/eng.pdf

Van der Bent, A.J., 1990, 'Justice, peace and the integrity of creation: A short bibliography', Exchange. Journal of Missiological and Ecumenical Research 19(3), 254-266.

Weber-Schnitter, M., [1926] 1988, Max Weber: A biography, transl. and ed. H. Zohn, Routledge, London.

Wikipedia, 4 July 2017, 'Lukas Vischer [theologian]', viewed 08 October 2017, from https://en.wikipedia.org/wiki/Lukas_Vischer_(theologian)

World Communion of Reformed Churches, 2004, The Accra confession, viewed 09 October 2017, from http://wcrc.ch/accra/the-accra-confession 